\title{
Pembinaan Teknik Bercocok Tanam Hidroponik Tanaman Obat di Perumahan Josroyo
}

\author{
Ika Purwidyaningrum, Iswandi, Meta Kartika Utari \\ Universitas Setia Budi, Indonesia \\ ikafarmasiusb@gmail.com
}

Received: $29^{\text {st }}$ January | Accepted: $29^{\text {th }}$ July 2020 | Publihsed: $20^{\text {th }}$ August 2020

Key word:

Hydroponic;

biopesticides;

traditional herb

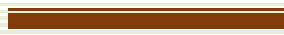

Key word:

Hydroponic;

biopesticides;

traditional herb

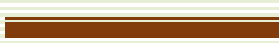

\section{Abstract}

The development of the Hydroponic Planting Technique for Medicinal Planting in the Central Java Josroyo Housing was carried out with the aim of improving the quality of health and the economy of the community. Pollution is a daily consumption for residents living in big cities and densely populated settlements. On free roads, motor vehicle fumes mixed with cigarette smoke are almost inevitable. Health research about cigarette smoke that causes lung cancer is not new and widely reported by researchers. Hydroponics is a method of planting that is positive for health. Consuming vegetables and medicinal plants hydroponics is better than conventional vegetables and free of pesticides so it is healthy. Vegetables and medicinal hydroponic drugs are fresher and tastier than similar products from the market or vegetable vendors. The durability of vegetables and hydroponic medicinal plants is recognized relatively longer than vegetables grown above ground. The advantages of hydroponic planting methods are saving land, saving water, without pesticides, free of weed disturbances, on-target nutrition as well as saving land and labor so as to answer the problem of planting in Josroyo housing.

\section{Abstract}

Pengembangan Teknik Tanam Hidroponik untuk Tanaman Obat di Perumahan Josroyo Jawa Tengah dilakukan dengan tujuan untuk meningkatkan kualitas kesehatan dan perekonomian masyarakat. Pencemaran merupakan konsumsi sehari-hari bagi penduduk yang tinggal di kota besar dan pemukiman padat penduduk. Di jalan bebas hambatan, asap kendaraan bermotor yang bercampur asap rokok hampir tidak bisa dihindari. Riset kesehatan tentang asap rokok penyebab kanker paru bukanlah hal baru dan banyak dilaporkan oleh para peneliti. Hidroponik merupakan salah satu cara menanam yang positif bagi kesehatan. Mengkonsumsi sayur mayur dan tanaman obat hidroponik lebih baik dari pada sayur mayur konvensional dan bebas pestisida sehingga sehat. Sayuran dan obat hidroponik obat lebih segar dan enak dibandingkan produk sejenis dari pasar atau pedagang sayur. Daya tahan sayuran dan tanaman obat hidroponik diakui relatif lebih lama dibandingkan sayuran yang ditanam di atas tanah. Keunggulan metode tanam hidroponik adalah hemat lahan, hemat air, tanpa pestisida, bebas gangguan gulma, nutrisi tepat sasaran serta hemat lahan dan tenaga kerja sehingga menjawab permasalahan penanaman di perumahan Josroyo. 


\section{PENDAHULUAN}

Pada tahun 1963 muncul istilah hidroponik yang diberikan untuk hasil penelitian yang dilakukan oleh Dr. WF. Gericke, seorang agronomis dari Universitas California, Amerika Serikat. Penelitiannya berupa tanaman tomat setinggi 3 meter yang penuh buah dan ditanam dalam bak berisi mineral hasil uji cobanya. Sejak itulah istilah hidroponik berkembang (Herwibowo \& Budiana, 2015)

Gericke pun menjadi headline di surat kabar. bahkan, dia sempat dinobatkan menjadi orang berjasa abad ke-20. Hidroponik tidak lagi sebatas skala penelitian saja. Hidroponik dapat diterapkan dengan teknik yang sederhana oleh siapa saja, termasuk ibu rumah tangga (Herwibowo \& Budiana, 2015)

Hidroponik berasal dari bahasa Yunani, yaitu hydro yang berarti air dan ponos yang berarti daya. Hidroponik dikenal sebagai soilless culture atau budi daya tanaman tanpa tanah. Istilah hidroponik digunakan untuk menjelaskan tentang cara bercocok tanam tanpa menggunakan tanah sebagai media tanamnya. Istilah bercocok tanam tanpa tanah dikenal dengan hidroponik. Hal ini termasuk juga bercocok tanam di dalam pot wadah lainnya yang menggunakan air atau bahan porous lainnya, seperti pecahan genting, pasirkali, kerikil dan gabus putih/ Styrofoam.

Salah satu cara untuk mendapatkan sayuran segar dan obat tradisional adalah menanam sendiri sayuran dan tanaman obat. Beberapa tahun terakhir, urban farming menjadi gaya hidup yang disukai oleh penduduk perkotaan atau yang ada di perumahan. Urban farming atau pertanian kota adalah gerakan menanam sendiri makanan baik sayur atau obat di rumah dan memanfaatkan lahan yang ada di rumah (Puriandi, 2013).

Penduduk warga Perumahan Josroyo Indah RT 7 RW 20 merupakan perumahan padat penduduk dan memiliki lahan yang sempit di rumahnya. Keterbatasan lahan yang dimiliki warga membuat warga tidak dapat leluasa untuk menanam tanaman di rumahnya. Meski demikian, warga Perumahan Josroyo merupakan warga dengan keinginan maju yang kuat terutama untuk dapat berdaya dan hidup sehat.

Berdasarkan gambaran aktifitas kegiatan dan permasalahan bercocok tanam serta potensi yang dimiliki oleh penduduk warga Perumahan Josroyo Indah Rt 7 Rw 20 dapat dirumuskan permasalahan sebagai berikut: 
1. Tidak semua orang di Perumahan Josroyo Indah memiliki lahan untuk menanam tanaman.

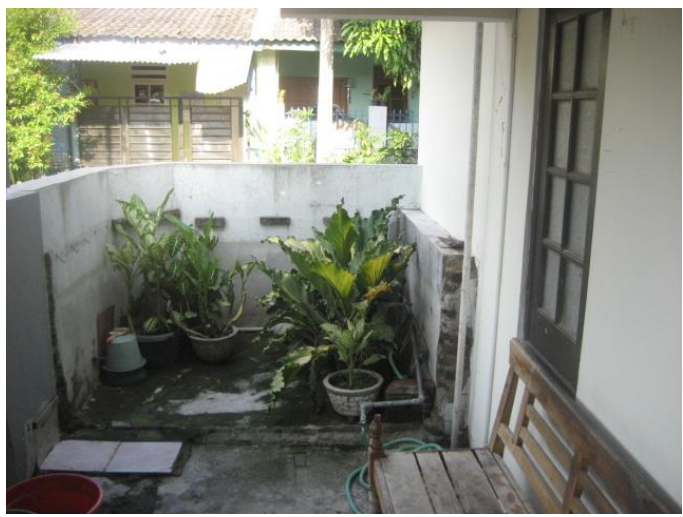

Gambar 1. Lahan sempit yang ada di salah satu warga perumahan Josroyo

2. Perumahan Josroyo adalah perumahan yang bersih dan nyaman tetapi tidak cukup luas untuk menanam sayuran dan tanaman obat yang bersih dan segar.

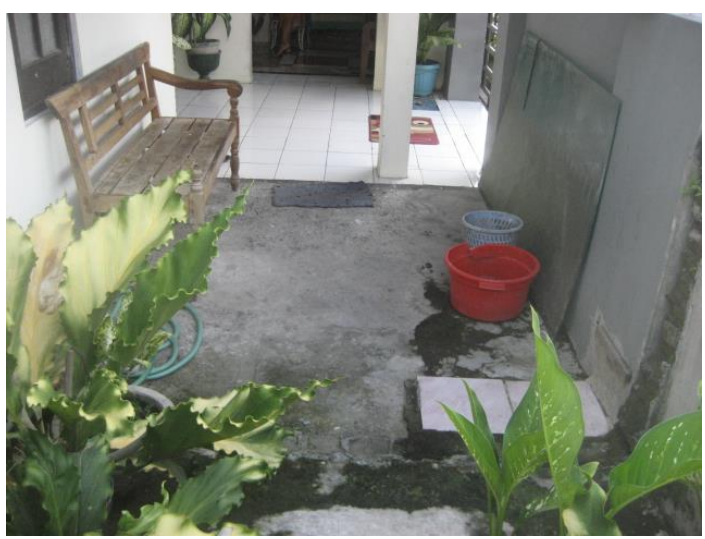

Gambar 2. Lahan bersih disalah satu rumah warga perumahan Josroyo

3. Tekanan hidup yang berat membuat sebagian orang mengalami stress tak terkecuali penduduk di Perumahan Josroyo, belum lagi isu pangan, termasuk sayuran yang tercemar residu serta istilah back to nature pengobatan tradisional yang lebih disukai masyarakat saat ini.

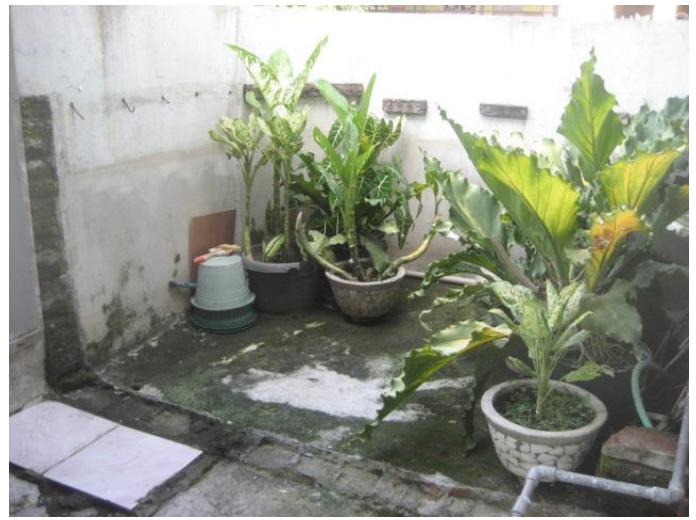

Gambar 3. Halaman rumah salah satu warga perumahan Josroyo

4. Kemampuan ekonomi warga Perum Josroyo Indah Rt 7 Rw 20 cukup memadai tetapi dibutuhkan sumber pendapatan baru yang mampu meningkatkan taraf ekonomi warga.

Berdasarkan kondisi inilah tim pengabdi melakukan pengabdian pembinaan teknik bertanam hidroponik untuk tanaman obat.

Target luaran yang ingin dicapai dari pengabdian ini antara lain :

1. Warga perumahan Josroyo memahami tentang tanaman yang berpotensi sebagai obat tradisional

2. Teknik bercocok tanam hidroponik tanaman obat yang tepat bagi warga perumahan Josroyo Indah Rt 7 Rw 20

\section{METODE}


Metode pengabdian yang dilakukan adalah:

1. Observasi. Pada saat observasi, tim menemui beberaa warga dan ibu RT untuk memotret lingkungan perumahan, melakukan analisa dan kelayakan lingkungan untuk di terapkan penanaman teknik hidroponik (Roidah, 2015).

2. Pelaksanaan pengabdian adalah "before after question". Pertama, tim menjelaskan materi pengabdian yang akan di sampaikan oleh masing-masing pengabdi yaitu meliputi tanaman herbal berkhasiat obat tradisional, teknik bercocok tanam hidroponik tanaman obat dan teknik pemupukan tanaman hiroponik. Materi di sampaikan dengan penjelasan langsung beserta simulasinya. Selanjutnya tim pengabdi membimbing peserta melakukan teknik penanaman hidroponik.

3. Metode evaluasi dilaksanakan dengan survey secara langsung di beberapa rumah untuk memastikan bibit tanaman obat di tanam secara benar sesuai teknik hidroponik. Selanjutnya di lakukan evaluasi dan memberikan masukan dan saran kepada warga.

\section{HASIL}

Hasil observasi menyatakan bahwa perumahan Josroyo RT 7 RW 20 layak untuk dilakukan pembinaan hidroponik. Didukung dengan keinginan dari Ibu-ibu penggerak yang bersemangat untuk mengetahui cara lebih lanjut mengenai hidroponik. Terdapat 15 orang yang menjadi voluntary untuk dilatih bertanam tanaman obat dengan hidroponik. Hal ini senada dengab pengabdian sebelumnya yang menyatakan bahwa pemberdayaan Ibu-bu PKK dalam pelatihan hidroponik dapat dilaksanakan (Ruswaji \& Chodariyanti, 2020).

Pelaksanaan pengabdian dilakukan bersama dengan 15 orang dengan cara ceramah mengenai pengetahuan umum hidroponik dan jenis tanaman herbal serta teknik-teknik dalam hidroponik. Tanaman obat dan herbal yang dikenalkan pada pengabdian ini adalah:

1. Lemon balm (anti virus, anti bakteri, herpes simplex)

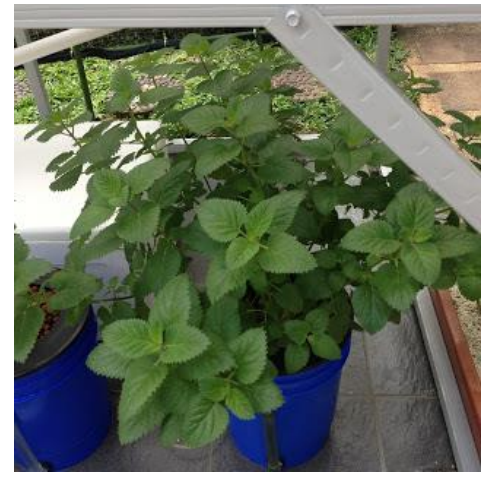

Gambar 4. Lemon Balm 
2. Sage: pengusir nyamuk (dengan dikeringkan dan dibakar)

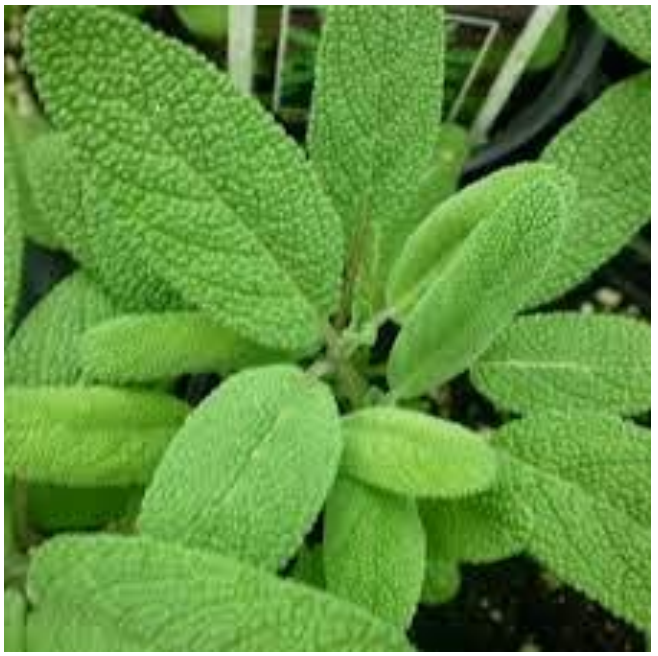

Gambar 5. Daun Sage

3. Sledri (Penurun tekanan darah, sayuran)

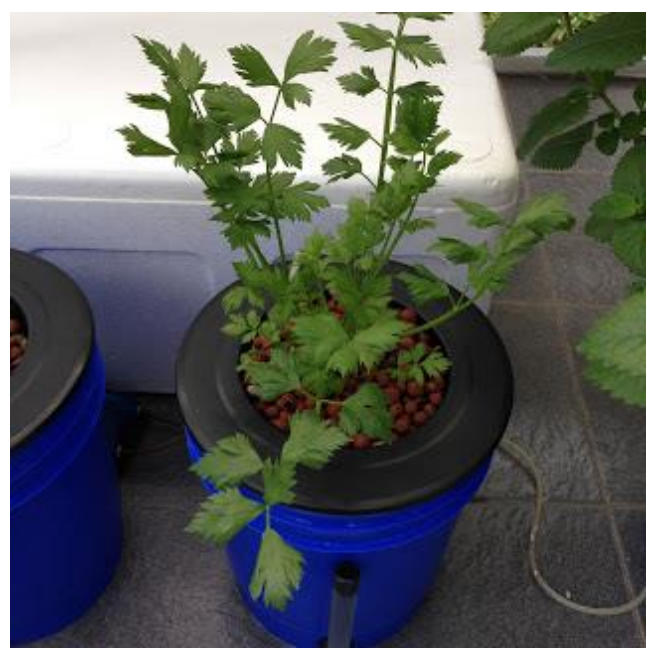

Gambar 5. Tanaman Sledri

Tim pengabdi memberikan contoh tatacara melubangi media tanam atau rockwool dan melakukan penanaman biji seledri. Metode tanam hidroponik yang dipraktekkan adalah wick system. Hasil Quisioner before after ini dilakukan Analisa statistic paired sample t test.
PEMBAHASAN

Materi mengenai bercocok tanam hidroponik serta praktik yang dilakukan adalah sebagai berikut:

\section{Cara Bertanam Hidroponik}

Penggunaan media teknik hidroponik dibagi dua : menggunakan media atau hanya menggunakan larutan media. Yang pertama, hidroponik dengan menggunakan media. Media tanam padat yang digunakan tetap bersih bukan tanah kotor. Media tidak mengandung bahan organik. Kalaupun menggunakan bahan organik sifatnya hanya padatan, itupun jumlahnya hanya sedikit.. Teknik yang menggunakan media padat yakni teknik statis, pasang surut, irigasi tetes, passive sub irrigation dan run to waste.

Pada dasarnya cara bertanam hidroponik sama dengan bertanam pada umumnya tetapi pada system hidroponik tidak menggunakan tanah sebagai media tanam. Dengan hidroponik dapat melakukan pemupukan dan penyiraman secara Bersama sehingga memudahkan pekerjaan dan tepat sasaran. Pada hidroponik media yang digunakan adalah air. Sedangkan media padatan seperti sekam, zeolite, hidroton, pasir dan cocopeat berfungsi sebagai penunjang akar tanaman bukan sebagai media nutrisi (Mustikarini dkk., 2019). 


\section{Macam-macam Teknik Hidroponik}

\section{System NFT (Nutrient Film Technique)}

Sistem ini adalah teknik pemberian larutan nutrisi yang sangat dangkal. Air yang mengandung semua nutrisi terlarut tersebut diberikan secara terus menerus selama 24 jam. Peralatan: talang air, pompa listrik, net pot, tutup talang, pralon, bak penampung nutrisi.

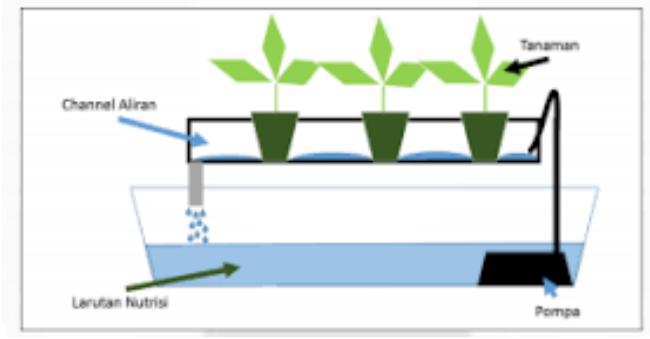

Gambar 6. Teknik NFT

\section{NFT system terbuka}

Secara prinsip sama, metode hidroponik sederhana yang bekerja mengalirkan air, oksigen dan nutrisi secara terus-menerus dengan ketebalan arus sekitar $3 \mathrm{~mm}$. Tanaman di sangga dengan sedemikian rupa sehingga akar tanaman menyentuh nutrisi yang diberikan. Rak talang dibuat miring dengan salah satu sisi lebih tinggi dari sisi lainnya, yaitu sebesar 2-5\% dari Panjang alat agar arus dapat mengalir dengan lancer dengan kecepatan debit air 1-2 liter/ menit. Peralatan: talang air, pompa listrik, net pot, tutup talang, pralon, bak penampung nutrisi.

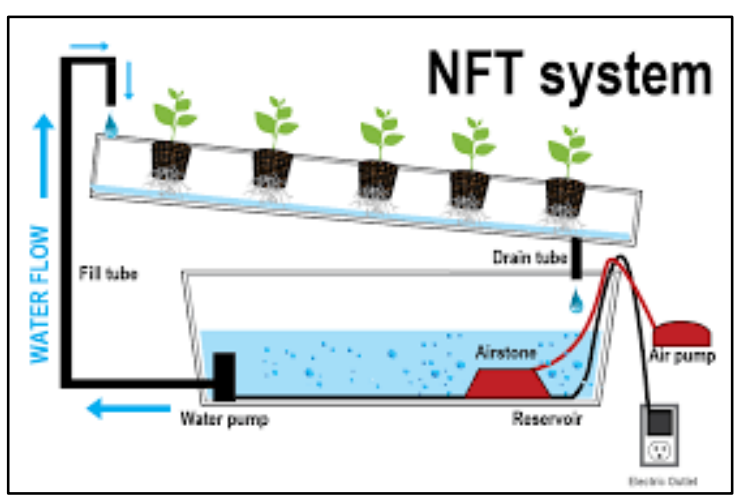

Gambar 7. Teknik NFT Terbuka

3. Sistem fertigasi (fertilizer + drip irrigation)

Sistem fertigasi merupakan system yang paling banyak digunakan di dunia pertanian. Sistem ini merupakan pengembangan dari drip irrigation (irigasi tetes), tanaman disiram dengan cara meneteskan air. Modifikasinya pada system fertigasi, yaitu tanaman tidak hanya diberi pengairan berupa tetesan air, tetapi air yang di teteskan juga telah dicampur dengan nutrisi. Peralatan: talang air, pompa listrik, net pot, tutup talang, pralon, bak penampung nutrisi, alat penetes, waktu pengatur.

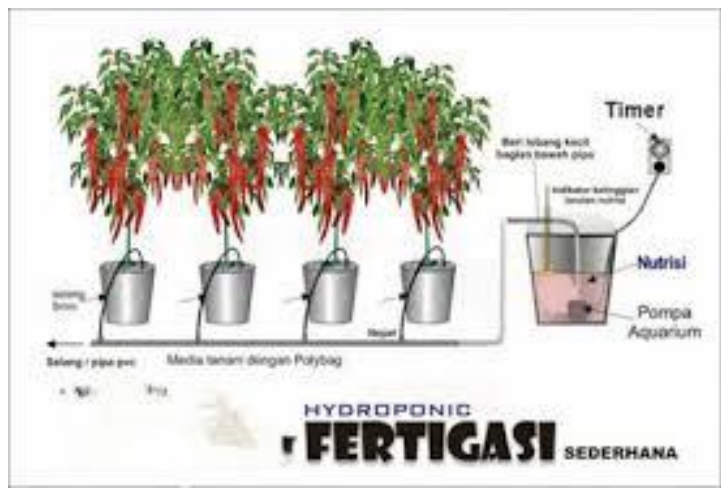

Gambar 8. Sistem Fertigasi

\section{9 || Journal of Dedicators Community Unisnu Jepara}


4. Wick system

System wick dikenal dengan sistem sumbu merupakan metode dalam bertanam secara hidroponik sederhana. Teknik ini memanfaatkan gaya kapilaritas pada sumbu untuk mengantarkan air dan nutrisi ke akar tanaman sehingga akar dapat menyerap unsur-unsur hara yang disediakan. Metode ini sangat mudah karena pembuatannya tidak membutuhkan peralatan yang banyak. Peralatan: bak penampung nutrisi, net pot, sumbu, styroform.

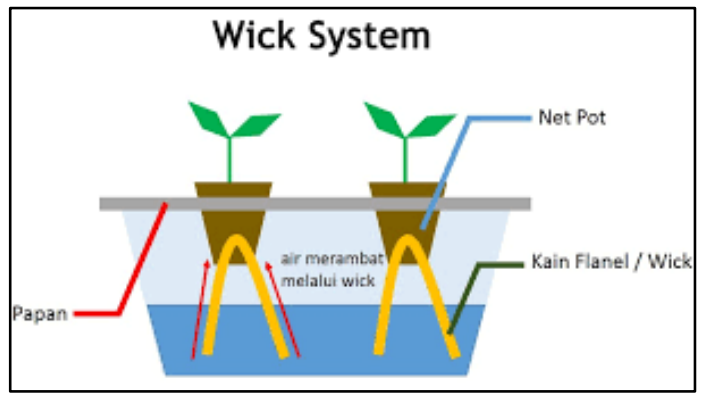

Gambar 9. Sistem Wick

\section{Aeroponic}

Teknik ini merupakan system hidroponik yang menggunakan teknologi tinggi. Seperti pada system NFT, media tanamnya udara. Akar-akar menggantung di udara dikabutkan oleh larutan air nutrisi. Pengabutan ini biasanya dilakukan oleh nozzle setiap beberapa menit sekali. Karena akar-akar terekspos diudara seperti pada system NFT, akar- akar bisa cepat mengering jika pengaturan mengabutan terganggu. Air dan nutrisi yang telah disemprotkan akan masuk kembali ke bak penampungan untuk disemprotkan kembali. Peralatan: pompa listrik, net pot, styroform, pralon, bak penampung nutrisi, alat pengabut, waktu pengatur.

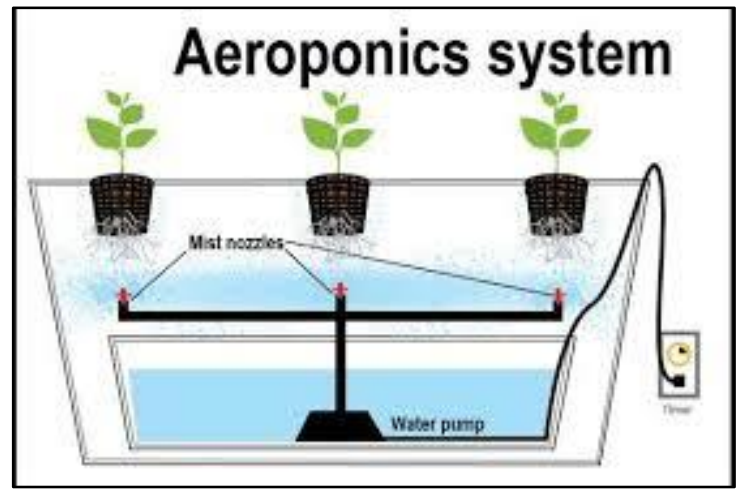

Gambar 10. Sistem Aeroponik

\section{Floating hydroponic}

Floating hydroponic system (FHS) merupakan budi daya sayuran dengan cara menanamkan sayuran pada lubang styroform yang mengapung diatas permukaan larutan nutrisi dalam suatu bak penampung atau kolam sehingga akarnya terapung atau terendam dalam larutan nutrisi. Pada system ini, larutan nutrisi tidak disisrkulasikan, tetapi dibiarkan pada bak penampungan dan dapat digunakan lagi dengan cara mengontrol kepekatan larutan dalam jangka watu tertentu. Hal ini perlu dilakukan karena akan terjadi 
pengkristalan atau pengendapan nutrisi didasar kolam dalam jangka waktu yang cukup lama sehingga dapat mengganggu pertumbuhan sayuran. Peralatan: net pot, styroform, bak penampung nutrisi.

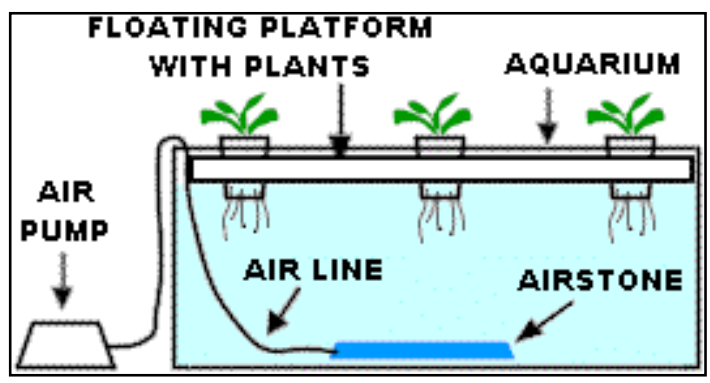

Gambar 11. Sistem Floating Hydroponic

Selain materi dasar tentang sistem hidroponik, tim pengabdi juga menyampaikan materi mengenai beberapa aspek penting yang digunakan untuk metode sesuai panduan hidroponik (Herwibowo \& Budiana, 2015). Peralatan atau aspek yang digunakan adalah sebagai berikut:

\section{Pupuk Hidroponik}

1. Media tumbuh

Media Tanaman berguna penopang akar untuk tumbuh. Dalam system hidroponik NFT, media tanamnya bukanlah tanah, tetapi lubang tanam. Pupuk diberikan kepada sayuran untuk tumbuh dan berkembang. Dalam hidroponik istilah pupuk disebut nutrisi. Perlu perhitungan yang cermat jumlah dari masing-masing unsur hara sesuai dengan kebutuhan tanaman.
2. Nutrisi lengkap

Nutrisi hidroponik adalah pupuk hidroponik lengkap yang mengandung semua unsur hara mako dan mikro yang diperlukan tanaman hidroponik. Pupuk tersebut diformulasi secara khusus, sesuai jenis dan fase pertumbuhan tanaman.

3. Bentuk larutan

Pupuk hidroponik harus larut sempurna. Hindari bahan baku yang memiliki daya larut rendah. Apabila berdaya larut rendah dimasukkan kedalam air, akan muncul endapan berupa butiran yang dapat tersedot pompa, lalu masuk melalui selang dan terdistribusi ke talang. Endapan ini dapat menumpuk di selang sehingga menghambat aliran air. Akibatnya, tanaman hidroponik terancam mati.

4. Bahan baku

Hidroponik system NFT membutuhkan pupuk dengan daya larut yang baik agar tidak ada endapan yang muncul jika dimasukkan ke dalam air. Bahan-bahan tersebut dapat di beli di toko kimia dan dijual dalam bentuk cairan. Bahan perbentuk kristal, semisal pupuk SP-36 yang dapat dibeli di toko saprotan dapat menyebabkan butiran. 
5. Unsur-unsur penting

Ada 12 jenis bahan kimia yang biasa dipakai dan semuanya mengandung unsur yang berguna bagi tanaman hidroponik. Kedua belas unsur tersebut adalah: nitrogen, fosfor, kalium, kalsium, magnesium, sulfur, boron, besi, mangan, tembaga, seng, molibneum. Dari 12 unsur tersebut terdapat enam unsur utama, yaitu nitrogen, fosfor, kalium, magnesium, kalsium dan sulfur. Karena jumlahnya banyak, unsur utama disebut unsur makro. Sementara unsur-unsur lain disebut unsur mikro karena dibutuhkan dalam jumlah sedikit. Unsur-unsur tersebut antara lain boron, suprum, besi, mangan, seng, molibden.

\section{Komposisi}

Istilah unsur makro dan mikro ini merujuk pada komposisinya, jumlah dan dosis yang diberikan untuk sayuran. Unsur makro harus lebih banyak karena memang dibutuhkan sayuran dalam jumlah banyak. Jumlah unsur mikro cenderung sedikit. Meskipun demikian, masing-masing unsur tersebut memegang eranan penting dalam pertumbuhan sayuran dan tanaman obat. Oleh karena itu, manfaat dan gejala kekurangannya perlu dipahami untuk menekan resiko kegagalan.
Tim pengabdi juga menyampaikan jenis sayuran atau buah yang dapat ditanam dengan sistem hidroponik, diantaranya: selada, bayam, kangkung, mentimun, tomat, cabe, daun bawang, melon, dan semangka (Rakhman, 2015).

Peserta menyimak dengan baik apa yang disampaikan oleh tim pengabdi, selain itu untuk mempertajam pemahaman peserta, dilakukan juga diskusi dan tanya jawab.

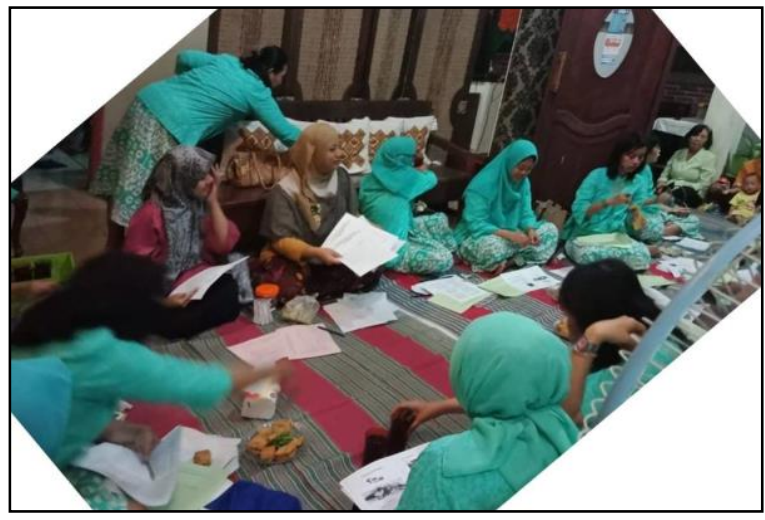

Gambar 12. Pemateri sedang menyampaikan materi

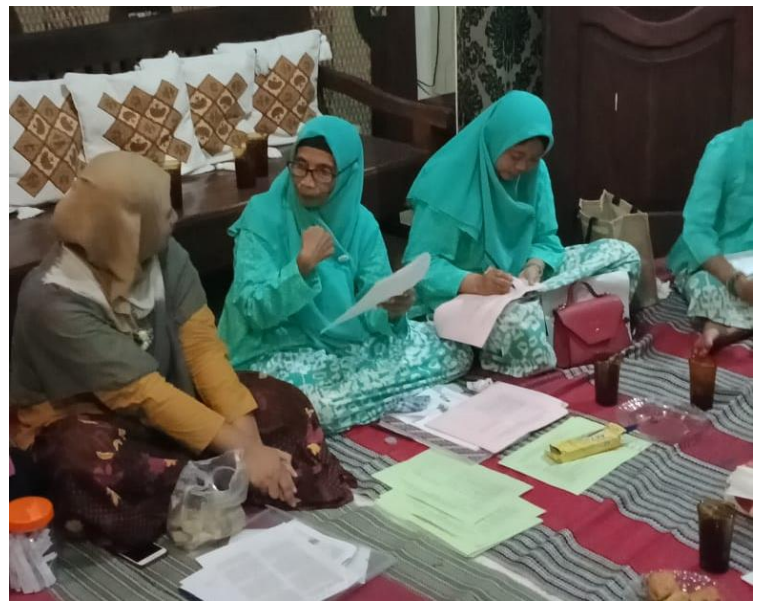

Gambar 13. Diskusi dan Tanya Jawab 
Berdasarkan kesepakatan dan melihat pada tingkat kemudahan, maka teknik hidroponik yang kemudian dipraktikkan adalah teknik NFT (Nutrient Film Technique) yang dikombinasikan dengan Teknik Sub-Irigasi Pasif.

Teknik sederhana sub-irigasi pasif selanjutnya disebut SIP juga banyak digunakan para pelajar untuk memahami prinsip hidroponik sekaligus prinsip kapilaritas. Wadah tanaman dan wadah nutrisi pada teknik SIP terpisah menjadi dua bagian.

Teknik pasif sedikit berbeda dengan teknik statis. Kedua teknik ini menggunakan larutan yang tidak disirkulasikan. Bedanya, sub-irigasi pasif memakai media perantara untuk mengubungkan tanaman dengan larutan nutrisi. Nutrisi diperoleh tanaman dengan bantuan sembu sebagai perantara sehingga ada pula yang menyebutnya teknik sumbu. (Kunto Herwibowo, 2014)

Sistem sumbu tergolong murah dan tidak memerlukan banyak biaya karena memanfaatkan bahan bekas. Sumber biaya tertinggi hanya berasal dari benih dan nutrisi. Dalam teknik sumbu, sejatinya akar tanaman dan media tanam tidak menyentuh larutan sama sekali. Namun pada beberapa kasus contohnya instalasi sederhana yang terbuat dari botol bekas air mineral misalnya seiring pertumbuhan tanaman dan ukuran wadah yang terbatas, akar lamakelamaan akan memaanjang dan menyentuh media. Teknik yang kerap disebut semi hidroponik itu cocok untuk tanama epifit seperti anggrek dan bromeliad tetapi tidak menginginkan akar terendam basah.

Salah satu penerapan teknik SIP yakni tanam system sumbu atau wick sytem. Untuk rakitan sederhana, wadah yang digunakan dapat berbahan plastic maupun kaca. Asalkan dapat menampung cairan.

\section{Penanaman}

Ibu PKK melakukan praktik penanaman menggunakan media rockwool dengan menandai rockwool dengan menggunakan pena atau pulpen sebagai pembatas benih dengan ukuran rockwool $2 \mathrm{~cm} \times 2 \mathrm{~cm}$. Hal ini akan memudahkan pemotongan rockwool saat bibit yang tumbuh akan dipindahtanam. Setelah ditandai buat lubang tanam dengan cara menual menggunakan pensil atau pelubang masal.

Rockwool dapat dipotong setelah benih tumbuh atau sebelum memasukkan benih. Agar praktis, potong saat benih tumbuh. Tekstur yang lembut memudahkan rockwool dipotong dengan menggunakan penggaris. Selipkan benih satu per satu. Jika terlalu kecil gunakan bantuan pinset atau

\section{3 || Journal of Dedicators Community Unisnu Jepara}


sebatang kayu runcing. Posisi benih jangan terlalu dalam. Cukup agar terlindung sedikit agar tidak lepas. Kemudian basahkan rockwool dengan cara merendamnya dalam air. Benih yang bagus akan tumbuh 2-4 hari setelahdisemai. Sekitar 10-14 hari kemudian tumbuh 2-4 helai daun sejati. Itu tanda bibit siap dipindah tanam ke meja remaja atau langsung ke meja produksi.

\section{Pindah tanam}

Pembibitan dan pembesaran bisa dilakukan pada wadah yang sama. Untuk media rockwool pemindahan tanaman terlebih dahulu dilakukan dengan memotong motong rockwool sesuai batas yang dibuat.

Bibit sebaiknya sudah cukup kuat saat dipindah pada meja produksi atau pembesaran. Ciri penjelas bibit siap dipindahkan yakni terbatas 3-4 lembar daun sejati. Umur bibit sekitar 7-14 hari tergantung jenis tanaman dan kecepatan tumbuhnya.

\section{Rakit dan aplikasi :}

1. Siapkan baki setinggi $20 \mathrm{~cm}$

2. Buat lubang pada papan stirifoam yang berukuran kotak selebar mulut baki sebanyak 6 lubang

3. Isi baki dengan nutrisi hingga setengah tinggi baki
4. Bibit yang siap dipisahkan ke wadah pembesaran dimasukkan dalam net pot

5. Letakkan net pot yang telah dilengkapi sumbu pada lubang tanam

6. Panen setelah tanaman dewasa.

Partisipasi Mitra dalam hal ini adalah masyarakat perum Josroyo Indah RT 7 RW 20 mampu melakukan praktek penanaman dengan teknik hidroponik sehingga mampu menjawab permasalahan warga yaitu berupa kesehatan dan ekonomi. Outcome dari pengabdian ini adalah beberapa dari warga RT7 RW 20 Perumahan Josroyo dapat melakukan teknik bercocok tanam hidroponik dengan metode wick system. Salah satu warga yang berhasil melaukan teknik cocok tanam hidroponik adalah ibu Rita, ibu Joko dan ibu Wahyu.

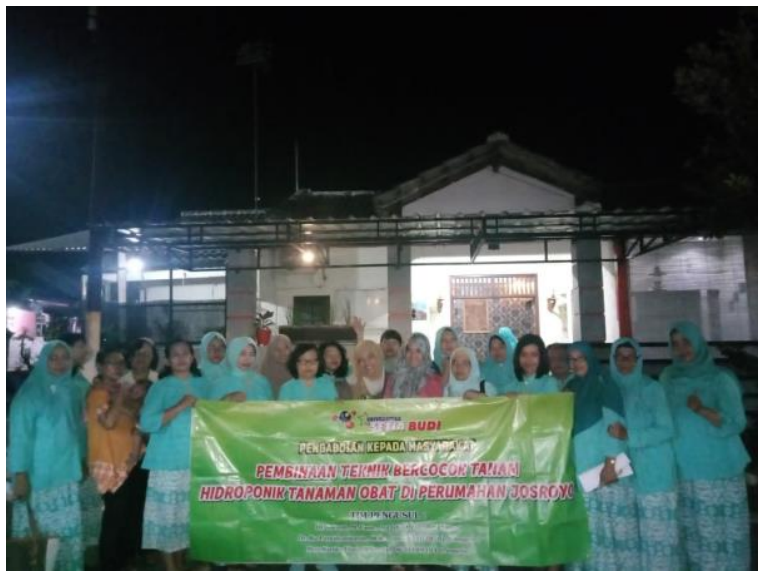

Gambar 14. Foto bersama peserta

Berdasar hasil kuisioner yang diisi oleh peserta dan sudah diolah secara statistik menunjukkan bahwa sig $<0,05$ artinya 
bahwa terdapat perbedaan bermakna pemahaman peserta pengabdi sebelum pemaparan materi dan setelah pemaparan materi serta melakukan praktik bersama. Hal ini menunjukkan bahwa pengabdian menghasilkan manfaat bagi mitra (Roidah, 2015).

\section{KESIMPULAN}

1. Warga perumahan Josroyo memahi tanaman obat yang berpotensi sebagai obat tradisional

2. Warga perumahan Josroyo dapat melakukan penanaman tanaman obat secara hidroponik dengan metode wick system

\section{SARAN}

1. Perlu dilakukan penerapan Teknik bercocok tanam tanaman obat skala produksi (lebih bayak hasil)

2. Perlu dilakukan kerjasama dengan mitra supplier penerima hasil tanam hidroponik secara berkelanjutan.

\section{UCAPAN TERIMAKASIH}

Ucapan terimakasih ditujukan kepada LPPM Universitas Setia Budi yang telah mendanai pengabdian ini secara menyeluruh. Ucapan terimakasih juga tertuju kepada Bapak Kepala Desa Jaten, Ibu
Ketua RT 7 RW 20 Perumahan Josroyo serta warga RT RT 7 RW 20 Perumahan Josroyo yang telah memberikan tim pengabdi kesempatan untuk melakukan pengabdian masyarakat.

\section{DAFTAR PUSTAKA}

Herwibowo, K., \& Budiana, N. S. (2015). Hidroponik Portabel. Penebar Swadaya Grup.

Mustikarini, E. D., Santi, R., \& Inonu, I. (2019). Pemberdayaan PKK Desa Pagarawan melalui Budi Daya Tanaman Sayuran dengan Sistem Hidroponik. Agrokreatif: Jurnal Ilmiah Pengabdian kepada Masyarakat, 5(3), 173-180.

Puriandi, F. (2013). Proses perencanaan kegiatan pertanian kota yang dilakukan oleh komunitas berkebun di Kota Bandung sebagai masukan pengembangan pertanian kota di kawasan perkotaan. Journal of Regional and City Planning, 24(3), 227-240.

Rakhman, A. (2015). Pertumbuhan tanaman sawi menggunakan sistem hidroponik dan akuaponik $[\mathrm{PhD}$ Thesis]. FAKULTAS PERTANIAN. Roidah, I. S. (2015). Pemanfaatan lahan dengan menggunakan sistem

\section{5 || Journal of Dedicators Community Unisnu Jepara}


p-ISSN : 2548-8783

e-ISSN : 2548-8791

hidroponik. Jurnal Bonorowo, 1(2), 43-49.

Ruswaji, R., \& Chodariyanti, L. (2020).

Pemberdayaan Masyarakat Desa

Kepada Kelompok Ibu-Ibu Pkk dan

Karang Taruna melalui Program

Pelatihan "Hidroponik." Jurnal

Abdimas Berdaya: Jurnal

Pembelajaran, Pemberdayaan dan

Pengabdian Masyarakat, 2(01), 1-9. 